\title{
Nutrient loads from agricultural and forested areas in Finland from 1981 up to 2010-can the efficiency of undertaken water protection measures seen?
}

\section{Tattari, Sirkka}

2017-03

Tattari , S , Koskiaho , J , Kosunen, M , Lepisto , A , Linjama , J \& Puustinen, M 2017 , ' Nutrient loads from agricultural and forested areas in Finland from 1981 up to 2010-can the efficiency of undertaken water protection measures seen? ' , Environmental Monitoring and Assessment, vol. 189 , no. 3 , 95 . https://doi.org/10.1007/s10661-017-5791-z

http://hdl.handle.net/10138/309932

https://doi.org/10.1007/s10661-017-5791-z

unspecified

acceptedVersion

Downloaded from Helda, University of Helsinki institutional repository.

This is an electronic reprint of the original article.

This reprint may differ from the original in pagination and typographic detail.

Please cite the original version. 


\section{Nutrient loads from agricultural and forested areas in Finland from 21981 up to 2010 - Can the efficiency of undertaken water protection 3 measures seen?}

4 Sirkka Tattari $^{1)}$, Jari Koskiaho ${ }^{1)}$, Maiju Kosunen ${ }^{2)}$, Ahti Lepistö ${ }^{1)}$, Jarmo Linjama ${ }^{1)}$ and Markku Puustinen ${ }^{1)}$

$5 \quad{ }^{1)}$ Finnish Environment Institute, P.O. Box 140 (Mechelininkatu 34a), FI-00251 Helsinki, Finland

$6 \quad{ }^{2)}$ University of Helsinki, Department of Forest Sciences, P.O. Box 27

7 (Latokartanonkaari 7), FI-00014 University of Helsinki, Finland

8

Corresponding author: Sirkka Tattari, E-mail: sirkka.tattari@ymparisto.fi

11 Acknowledgements

12 We would like to thank Hannu Sirviö, Yrjö Kivinen and Juha Riihimäki from the Finnish Environment Institute

for providing runoff data of small catchments and for GIS map of arable land.

Key words: Long-term monitoring, nutrient loading, trend analyses, water quality, mitigation measures

\section{Abstract}

Long-term data from a network of intensively monitored research catchments in Finland was analyzed. We studied temporal (1981-2010) and spatial variability in nitrogen $(\mathrm{N})$ and phosphorus (P, from 1987) losses, both from agricultural and forestry land. Based on trend analysis, total nitrogen (TN) concentrations increased in two of the four agricultural sites and in most of the forested sites. In agricultural catchments, the total phosphorus (TP) trends were decreasing in two of the four catchments studied. Dissolved P (DRP) concentrations increased in two catchments and decreased in one. The increase in DRP concentration can be a result of reducing erosion by increased non-plough cultivation and direct sowing. In forested catchments, the TP trends in 1987-2011 were significantly decreasing in three of the six catchments, while DRP concentrations decreased significantly in all sites. At the same time, P fertilization in Finnish forests has decreased significantly, thus contributing to these changes. The mean annual specific loss for agricultural land was on average $15.5 \mathrm{~kg} \mathrm{ha}^{-1} \mathrm{yr}^{-1}$ for N and $1.1 \mathrm{~kg}$ ha ${ }^{1} \mathrm{yr}^{-1}$ for $\mathrm{P}$. In the national scale, total TN loading from agriculture varied between 34,000-37,000 $\mathrm{yr}^{-1}$ and total $\mathrm{P}$ loading 2,400-2,700 $\mathrm{yr}^{-1}$. These new load estimates are of the same order than those reported earlier, emphasizing the need for more efforts with wide-ranging and carefully targeted implementation of water protection measures. 
Non-point source loading, predominantly from agriculture, is recognised as a major source of anthropogenic nutrient loading to watercourses throughout the world (e.g. Collins et al. 2016; Rocha et al. 2015; Heathwaite et al. 1993; Sharpley et al. 1994; Foy and Withers 1995) and also in Nordic and Baltic countries (e.g. Kronvang et al. 1995; Stålnacke 1996; Lääne et al. 2002). In Finland, the major share of nutrient loading originates from agriculture (Rekolainen et al. 1997; Vuorenmaa et al. 2002). Although the area under cultivation in Finland is relatively small (7.4\%), there are many river basins where it may exceed 30\% (Räike et al. 2003). Fields are concentrated in southern and western Finland. Forests also contribute to diffuse pollution: they cover $78 \%$ of the total land area in Finland, of which forested peat lands cover one third. Forestry in Finland has been estimated to contribute on average $9 \%$ of the total $\mathrm{N}$ export, with dominance towards eastern and northern parts of the country: from $2-15 \%$ in the southern-mid-western Finland basins to $10-30 \%$ in the large northern basins (Lepistö et al. 2006). Forestry loading occurs from a mosaic of numerous treatment areas (cuttings, forest drainage), where the time period of the impact varies from site to site providing high uncertainties to load estimates. Besides forestry, natural background loading is also important in the north.

Climate change induced mild winters have become more common in the last couple of decades (e.g. IPCC 2013). Such mild winters - with occasional, heavy rainfall events - transmute the traditional flow patterns with predictable spring and autumn floods and low flow in midwinter into more unpredictable distributions of flow. In Finland, Korhonen and Kuusisto (2010) have detected clear trends in many seasonal flow time series, with increases in winter and spring mean flow together with earlier timing of the spring peak. An unwanted effect of these trends is the increased loading to surface waters due to the increased erosion and leaching of nutrients from unfrozen soil with thin or no snow cover (e.g. Koskiaho et al. 2010).

Small representative catchments, experimental plots, or river basins loaded mainly by non-point sources provide a framework to assess and monitor the non-point source nutrient loading. However, the transport of nutrients from diffuse sources is strongly influenced by a complex combination of temporal and spatial factors, such as fluctuating climatic and hydrological conditions, geomorphological characteristics, crop cycles and land-use practices (Vuorenmaa 2002; Kyllmar et al. 2006, 2014; Santos et al. 2015; Pacheco and Sanches Fernandes 2016).

During 1981-1995, in these same small catchments that are studied here, the agricultural loading level averaged $15 \mathrm{~kg} \mathrm{ha}^{-1} \mathrm{yr}^{-1}$ for nitrogen (N) and $1.1 \mathrm{~kg} \mathrm{ha}^{-1} \mathrm{yr}^{-1}$ for phosphorus, with no clear trends in total losses and concentrations. For forested catchments, the loading averaged $1.9 \mathrm{~kg} \mathrm{ha}^{-1} \mathrm{yr}^{-1}$ for nitrogen and $0.09 \mathrm{~kg} \mathrm{ha}^{-1} \mathrm{yr}^{-1}$ for P (Vuorenmaa et. al 2002). In 35 small agricultural catchments in Nordic and Baltic countries, loading ranged from 5 to $75 \mathrm{~kg} \mathrm{ha}^{-1} \mathrm{yr}^{-1}$ for nitrogen in 1994-1997, with significant within-country and inter-annual variation. The main explanations for this variability were runoff, fertilizer use (especially the amount of manure), soil type and erosion, but there was poor correlation between nitrogen losses and surpluses (Vagstad et al. 2004). 
The Finnish Agri-Environmental Programme FAEP, launched in 1995, forms the most important policy instrument for controlling agricultural nutrient loading. Since 2002, FAEP has covered about $93 \%$ of the agricultural area (Ministry of Agriculture and Forestry 2004; Aakkula and Leppänen 2014). Due to reduced fertilization limits of FAEP and increased fertilizer prices, national level $\mathrm{N}$ and $\mathrm{P}$ field balances have decreased 35\% and 60\%, respectively, in the period 1995-2013 (Aakkula and Leppänen 2014)._Increased non-plough cultivation and direct sowing have taken place in almost two thirds of earlier autumn-ploughed field areas (Farm Structure Survey / Agricultural Census 2010 - Farmland management). Additionally, 8,600 hectares of buffer zones and about 500 constructed wetlands and sedimentation ponds have been established after 1995 according to FAEP (Berninger et al. 2012).

The first studies made in the agricultural catchments after implementation of WFD indicated limited or no reduction of nutrient loads (Räike et al. 2003; Granlund et al. 2005). Later on, in the national MYTVAS followup study based on nutrient load monitoring in the agriculture-dominated river basins, the phosphorus load per hectare of cropland has nevertheless decreased in each programme period; being about $80 \%\left(0.72 \mathrm{~kg} \mathrm{ha}^{-1}\right)$ in the third period (2007-2013) of the level of the first period (1995-1999) $\left(0.90 \mathrm{~kg} \mathrm{ha}^{-1}\right)$. However, the nitrogen load on waterways from agriculture continued to grow during the second programme period (2000-2006). In the third programme period (2007-2013), the nitrogen load per hectare of cropland (12.9 $\left.\mathrm{kg} \mathrm{ha}^{-1}\right)$ had decreased somewhat, i.e. $7 \%$ from the level of the first period (13.9 $\left.\mathrm{kg} \mathrm{ha}^{-1}\right)$ (Aakkula and Leppänen 2014).

Most of the agri-environmental practices and measures are established on a field basis, but benefits may be realized in freshwaters lower in the river basin, or in coastal waters. For these reasons, there was a high demand to revisit the long-term data of small catchments, including both old published and new unpublished data. The small catchments are the missing link between field and river basin scales - on planning agri-environment programmes for WFD, on developing loading models and on the practical implementation of agri-environmental measures - in order to improve the state of watercourses.

The aim of this study was to evaluate 30-year long-term data (1981-2010 for nitrogen, 1987-2010 for phosphorus) from 12 small catchments in Finland. We compared the period without agri-environment measures before 1995 to the period with measures in order to look if impacts on loading levels can be seen. Further, we compared loading levels in agricultural and forested catchments, annual and monthly trends in nutrient concentrations and flow factors affecting changes in the catchments, together with factors affecting annual and year-to-year variability and variation between different catchments. In addition, continuous water quality data was used in one catchment to evaluate the accuracy of loading estimates for the period 2010-2013.

\section{Materials and Methods}

\section{Characteristics of small research catchments}

The national network of 37 small catchments was established in 1957, while monitoring of runoff water quality started in 34 of these catchments in 1962 (Vuorenmaa et al. 2002). Geological conditions in Finland, such as 
rather thin soil layers and impermeable bedrock, support the reliable estimation of water balance in these catchments. The catchments have no lakes and their earlier main purpose was to obtain hydrological information on the soil and climate conditions typical for Finland.

The catchments were divided into three classes: i) agricultural catchments (agricultural land area $39-100 \%$ ), ii) mixed catchments (agricultural land area 16-21\%) and iii) forested catchments (agricultural land area $<5 \%$ ). Haapajyrä is a special case within agricultural catchments, as it consists mainly of acid sulphate soils. Acid sulphate soils contain high amounts of sulphidic acids and the phosphorus loads are found to be lower and nitrogen loads higher compared to other agricultural catchments (Rekolainen 1989). A total of four agricultural catchments, two mixed and six forested, were included in this study; together they provide a good geographical coverage in different parts of Finland (Fig. 1, Table 1).

Fig. 1. Location of studied research catchments and the share of arable land.

The catchment areas vary between $0.12 \mathrm{~km}^{2}$ and $21.70 \mathrm{~km}^{2}$ (Table 1). The highest percentage of agricultural land is in Hovi (100\%), while Teeressuonoja, Huhtisuonoja and Vähä-Askanjoki are completely covered by forests and forested peatlands (Table 1). Most of the mineral soil in the forested catchments is non-graded moraine, and the coverage of peat soils is typically high: $13-50 \%$ in forested catchments with the exception of Laanioja. Most arable land in agricultural catchments is located on graded soils, with high proportions of silt and clay (Table 1).

\section{Agricultural and mixed catchments}

Fields in Löytäneenoja, Savijoki and Haapajyrä are located on flat areas with average slopes under $0.8 \%$, whereas the fields in Ruunapuro, Hovi and Latosuonoja are relatively steep for Finnish agricultural fields (Table 2). All crops in the catchment of Hovi consist of spring cereal, whereas in Löytäneenoja both spring cereals $(68 \%)$ and root crops $(27 \%)$ are cultivated. In addition to spring cereal $(70 \%)$, some autumn cereals $(17 \%)$ and root crops $(0.9 \%)$ are cultivated in Savijoki (Table 2). Considerable amounts of livestock occur in Savijoki (livestock unit LSU=238) and Haapajyrä (LSU=119), but in the other catchments the LSUs are negligible (Table 2).

Table 1. Area $\left(\mathrm{km}^{2}\right)$, percentage of agricultural land, and shares of graded soils, peat soils and moraines (\%) in the studied catchments. Numbers of catchments refer to Fig. 1.

Table 2. Average slope (\%) of agricultural fields and proportion (\%) of different crops and livestock units (LSU) in the agricultural and mixed catchments.

The tillage practices in the Hovi catchment vary from year to year: autumn ploughing has decreased from $100 \%$ in 1981-87 to 0-30\% in 2005-2010 (Table 3). Before 1987, the autumnal ploughing, which leaves the soil prone to erosion and nutrient losses, was the most common agricultural practice in Finland. At present, the greening of 
the fields has become much more common, e.g. during 2014 less than $30 \%$ of the field area was ploughed in the autumn or cultivated with winter grains. The most dominating practices nowadays are reduced tillage methods, and permanent grass cover is also in use. During 1991-1994 there was a national obligation to leave part of the field area fallow, of which two thirds was implemented as green fallow. In addition, the use of mineral fertilisers in agriculture has decreased drastically in Finland from the early 1990s to the present day (Fig. 2).

Fig. 2. Forest fertilisation area and the use of mineral $\mathrm{N}$ and $\mathrm{P}$ fertilisers in agricultural land in Finland, both during 1975-2011.

Table 3. The used tillage practice ( 1 to 4 ) and the corresponding share of the plant coverage areas ( $\%$ of the total arable area) during winter season (approximately Oct.-Apr.) in the Hovi research basin during 1981-2010.

\section{Forested catchments}

All of the forested small catchments represent managed forest land, where numerous year-to-year forestry practices have occurred (Vuorenmaa et al. 2002). The most important forestry practices in 1960-1990 (drainage, clear-cuttings, soil tillage, fertilising) in Huhtisuonoja, Kesselinpuro and Vähä-Askanjoki have been described by Kortelainen and Saukkonen (1998).

Forest drainage works had been conducted in $48 \%$ of Huhtisuonoja catchment, $30 \%$ of Kesselinpuro, $18 \%$ of Myllypuro and 8\% of Vähä-Askanjoki, respectively, before 1990 (Saukkonen and Kortelainen 1995). After that, in the 1990s and 2000s, more focus has been on supplementary drainage works (Metla Statistical Yearbooks), but detailed areas in most of these catchments after 1990 are not known. At present, the areas under forestry actions are much smaller than before 1990. In the Teeressuonoja catchment, there have been many clear-cuttings between 1985-2001. Meanwhile, the Huhtisuonoja catchment was extensively fertilised during 1985-1986 with P-fertilisers (70\% of the total area of peatland i.e. 156 ha, where $32.7 \mathrm{P} \mathrm{kg} \mathrm{ha}^{-1}$ was applied) (Pietiläinen and Rekolainen 1991; Vuorenmaa et al. 2002). The forest fertilisation area in Finland was highest in the mid-1970s $\left(250,000\right.$ ha year $\left.^{-1}\right)$, then decreased close to zero in the early $1990 \mathrm{~s}$, where after it has gradually risen but not to high levels (see Fig. 2). Although some data is available on practices from single basins, no database with a continuous survey of either forestry or agricultural practices unfortunately exists for all these research catchments.

\section{Monitoring of runoff and water quality}

\section{Runoff measurements, sampling and chemical analyses}

The runoff in all of the 12 study catchments was measured continuously by overflow weirs with water stage recorder, and stored to the hydrological database by the Finnish Environment Institute (SYKE) (Linjama 2012). Monitoring of water quality was mostly based on manual, grab water samples. Sampling was concentrated on spring and autumn high flow periods. Automatic flow-weighted water quality sampling (ISCO) has also been utilised in five of the catchments (Vuorenmaa et al. 2002). The number of automatic samples has varied between 
30 and 50 per year. On average for the whole monitoring period, sampling frequency has been quite high: annual samples have varied between 23-58 in agricultural catchments and between 12-42 in forested catchments, respectively.

In this study, total phosphorus (TP), dissolved reactive phosphorus (DRP), total nitrogen (TN) and nitrate nitrogen $\left(\mathrm{NO}_{3}-\mathrm{N}\right)$ concentrations were used for trends and loss estimates. Water quality variables were analyzed in the laboratories of SYKE or Regional Environment Centers, with methods based on international standards (Näykki et al. 2013). The DRP concentration was determined with a polycarbonate $(0.4 \mu \mathrm{m})$ filtration and by colorimetric spectrometer. Before 1986, analyzing was done without filtration. Therefore, the DRP data is only used from 1986 onwards. For the TP analysis, phosphorus was first digested with peroxodisulphate and then determined by the molybdenum blue method (Helcom 2004). The TN was digested with peroxodisulphate and

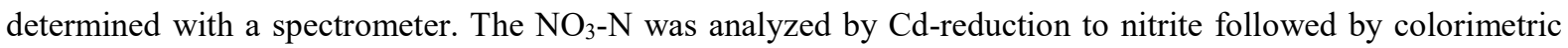
determination. Turbidity was determined with a nephelometric method. The suspended sediment was first filtered with polycarbonate $(0.4 \mu \mathrm{m})$ and then analyzed with gravimetric drying in $105{ }^{\circ} \mathrm{C}$.

\section{Continuous water quality measurements at Savijoki}

Continuous water quality measurements were carried out in Savijoki, using the S::can Nitrolyser probe (S::can Measuring Systems). The $\mathrm{NO}_{3}-\mathrm{N}$ and turbidity were measured with a $5 \mathrm{~mm}$ measuring path length with a measurement range of $0.3-70 \mathrm{mg} \mathrm{l}^{-1}$ for $\mathrm{NO}_{3}-\mathrm{N}$ and 5-1,400 FTU (Formazin Turbidity Unit) for turbidity (Linjama et al. 2009). The accuracy and measuring range for $\mathrm{NO}_{3}-\mathrm{N}$ is dependent on turbidity. The whole scale can be measured in clear water, but if turbidity increases to near the upper limit of the scale, $\mathrm{NO}_{3}-\mathrm{N}$ cannot be measured. If turbidity increases to $250 \mathrm{FTU}$, an $\mathrm{NO}_{3}-\mathrm{N}$ concentration of $<5 \mathrm{mg} / \mathrm{l}$ can still be measured (Linjama et al. 2009). The probe was calibrated for the local conditions with utilisation of comparable readings from laboratory analysis.

The measuring path and windows of the probe were cleaned with compressed air before each measurement. Once a month the probe was taken out and cleaned manually and twice a year checked and calibrated with distilled water (Linjama et al. 2009). Water level was measured with a pressure probe (Keller AG) with a $1 \mathrm{~mm}$ resolution. Discharge was determined according to a weir-specific stage-discharge curve from the water level measurements (Linjama et al. 2009).

\section{Calculation methods}

\section{Nutrient loads}

Slightly differing methods, such as interpolation method (Rekolainen 1989; Vuorenmaa et al. 2002) and the monthly mean method (Helcom 2014), have been utilised when estimating nutrient losses from Finnish catchments. The periodic method was chosen to be used in this study as it has been found to have the highest general reliability (RMSE) for estimation of TN load (Kauppila and Koskiaho 2003). The periodic method was utilised for monthly and annual calculations of nutrient losses. In this method, the nutrient fluxes are first 
calculated for each day by using the daily discharge measurements. The daily concentrations are calculated based on the temporal midpoints of the observation days as illustrated in Fig. 3. The annual nutrient flux is calculated with the following equation:

$$
L_{a}=\sum_{i=1}^{365} c\left(t_{i}\right) \cdot Q\left(t_{i}\right)
$$

where $L_{a}$ is the annual nutrient flux

$c\left(t_{i}\right)$ is the concentration of the day $\mathrm{i}$

$Q\left(t_{i}\right)$ is the mean discharge of the day $\mathrm{i}$

Fig. 3. Schematic approach to the calculation of the concentrations over the studied period by using the periodic method.

In order to eliminate high year-to-year variation of runoff in load estimates, the annual flow-weighted concentrations were calculated by dividing the total annual load by the total annual runoff. Nutrient loads for 2010-2012 at Savijoki were also calculated according to the water quality samples measured in the laboratory and according to the continuous monitoring data.

\section{Trend analysis}

The non-parametric Mann-Kendall test was used for detection of monotonic trends in nutrient concentration and runoff time series. Trend analysis was done for the monthly means of TP, DRP, TN and $\mathrm{NO}_{3}-\mathrm{N}$ concentrations as well as for runoff for each small catchment. For this, we used the Multitest application (a VBA macro running in MS Excel) developed in Linköping University, Sweden. The basic principle of the Mann-Kendall trend test is to examine the signs of pairwise differences in the examined time series so that all previous observation values are subtracted from every observation value. If the sum of signs (test statistic) is zero there is no trend, if positive, the trend is increasing and if negative, the trend is decreasing. The statistical significance ( $p$-value) of the trend depends on how much the test statistic differs from zero.

The Multitest application is able to calculate the trend and its significance not only over the whole time series, but also for each month separately according to principles presented by Hirsch and Slack (1984). This feature is particularly useful in Finnish conditions, where seasonal variation of flow is high. Indeed, in terms of total annual loading, the concentrations during the months with high flow are much more significant than those observed during the months with low flow.

The trend analysis period was 1981-2011 for the concentrations and 1981-2010 for runoff. However, for P concentrations the trends were analysed for periods beginning in 1987 due to a fundamental change in laboratory procedure of $\mathrm{P}$ analyses. Statistical significance of the trends was divided as follows: strongly 
significant $(* * *, p<0.001)$, intermediately significant $(* *, 0.001<\mathrm{p}<0.01)$ and weakly significant $(*$, $2690.01<\mathrm{p}<0.05)$.

Continuous water quality monitoring

273 Continuous water quality and discharge measurements of the Savijoki catchment were utilised to compare traditional nutrient loading estimates, e.g. those calculated by the periodic method from the data collected by grab sampling, to the hourly data collected automatically. The measured concentrations for turbidity and $\mathrm{NO}_{3}-\mathrm{N}$ were calibrated with the laboratory data. In total, 139 data pairs were utilised in order to form the calibration equations. The calibration equations and $\mathrm{R}^{2}$ values are shown in Table 4. In addition, the conversion equations were also calculated for TP load with on-line measured turbidity data and $\mathrm{TN}$ load with on-line measured $\mathrm{NO}_{3}$ $\mathrm{N}$ data.

Table 4. Calibration equations for turbidity (FTU) and nitrate nitrogen $\left(\mathrm{NO}_{3}-\mathrm{N}, \mathrm{mg} \mathrm{l}^{-1}\right)$, and conversion equations for total phosphorus (TP, $\mu \mathrm{g}^{1^{-1}}$ ) and total nitrogen $\left(\mathrm{TN}, \mathrm{mg}^{\mathrm{l}^{-1}}\right.$ ).

283

Results

Precipitation and variability in runoff and nutrient concentrations between catchments

During 1981-2010 the average annual precipitation sums decreased slightly (2-7\%) in all the other catchments except for two northern areas, Myllypuro and Laanioja, where the increases in annual average precipitation were $9 \%$ and $5 \%$, respectively (Table 5). As a result of lesser rainfall, the annual average runoff typically decreased by $4-7 \%$ in agricultural and forested catchments and by $11 \%$ in mixed catchments during the latter period (19952010).

Table 5. Average annual precipitation (mm) during 1981-1994 and 1995-2010 and the change (\%) in precipitation.

In Fig. 4, the boxplots of annual average runoff (1981-2010) for all 12 catchments are presented. On the whole, runoff and its variability seem to be rather similar for all land use types. The median runoff varied from 7.0 to $13.8 \mathrm{~s}^{-1} \mathrm{~km}^{-1}$. Slightly higher runoff values were observed in the northern forested catchments of Laanioja (13.8 $\left.1 \mathrm{~s}^{-1} \mathrm{~km}^{-1}\right)$, Vähä-Askanjoki $\left(12.81 \mathrm{~s}^{-1} \mathrm{~km}^{-1}\right)$ and Myllypuro $\left(11.81 \mathrm{~s} \mathrm{~s}^{-1} \mathrm{~km}^{-1}\right)$. In the southern to south-western agricultural catchments, median runoff varied from 7.0 to $12.81 \mathrm{~s} \mathrm{~s}^{-1} \mathrm{~km}^{-1}$. There was high variability between the years.

Fig. 4. Box-plot distributions of annual runoff during 1981-2010 in all 12 small catchments. The catchments (xaxis) are arranged with decreasing share of agricultural area from left to right. 
307 At the same time, large differences were observed in average TN concentrations in 1981-2010 (Fig. 5) between

308 these 12 catchments. The highest median values were measured in agricultural catchments, namely Hovi (4,380

$\left.309 \mu \mathrm{g} \mathrm{l}^{-1}\right)$, Löytäneenoja $\left(4,190 \mu \mathrm{g}^{-1}\right)$ and Haapajyrä $\left(6,320 \mu \mathrm{g} \mathrm{l}^{-1}\right)$. In the agricultural Savijoki catchment, the

310 median concentration was somewhat lower $\left(2,310 \mu \mathrm{g} \mathrm{l}^{-1}\right)$ though slightly higher than in the mixed catchments.

311 In forested catchments, the median $\mathrm{N}$ concentrations were much lower (range 119-968 $\mu \mathrm{g}^{-1}$ ). The year-to-year

312 variability in nitrogen concentrations was much higher for agricultural than forested catchments. The

313 exceptionally high concentrations were measured during the years 2003 (Savijoki), 2004 (Latosuonoja) and

3142006 (Teeressuonoja), i.e. not in the years when the highest flows were measured.

316 Fig. 5. Box-plot distributions of average annual nitrogen concentration during 1981-2010 in all 12 small catchments. The catchments (x-axis) are arranged with decreasing share of agricultural area from left to right.

319 Total P boxplot pattern (Fig. 6) differed somewhat from the above TN pattern. For instance, the variability in 320 annual average TP in 1987-2010 was considerably higher in the 100\% agricultural Hovi catchment than in the 321 other agriculture-dominated catchments. The variability was especially low in the forested catchments. The median TP concentration in the agricultural Hovi catchment was $290 \mu \mathrm{g} \mathrm{l}^{-1}$, and in the agricultural Löytäneenoja and Savijoki catchments $170 \mu \mathrm{g} \mathrm{l}^{-1}$. In the Haapajyrä catchment, which consists mainly of acid sulphate soils with high P retention, the median TP concentration was much lower, $79 \mu \mathrm{g} \mathrm{l}^{-1}$. In the forested catchments, the median TP concentration varied between 4-44 $\mu \mathrm{g}^{\mathrm{l}^{-1}}$.

Fig. 6. Box-plot distributions of average annual phosphorus concentration during 1987-2010 in all 12 small catchments. The catchments (x-axis) are arranged with decreasing share of agricultural area (from left to right).

The coefficients of variation for average annual runoff and concentrations of $\mathrm{TN}, \mathrm{NO}_{3}-\mathrm{N}$, org-N, TP and DRP were considerably higher in the agricultural catchments (average 0.36) than in the forested catchments (average 0.23 ). Generally, the coefficients of variation were under 0.40 , but higher values were observed in agricultural catchments and particularly in $\mathrm{NO}_{3}-\mathrm{N}$, TP and DRP concentrations. In general, the coefficients increased in the latter period apart from org-N, which remained at the same level, and DRP, which slightly decreased. No significant differences were observed between the different periods (Table 6).

Table 6. Coefficients of variation for annual average concentration values during 1981-1994 (for TP and DRP: 1987-1994) and 1995-2010 in the three groups of the studied catchments.

Nitrogen loads in the agricultural and mixed catchments Hovi, $13.2 \mathrm{ha}^{-1} \mathrm{yr}^{-1}$ for Löytäneenoja, $16.1 \mathrm{~kg} \mathrm{ha}^{-1} \mathrm{yr}^{-1}$ for Haapajyrä and $8.2 \mathrm{~kg} \mathrm{ha}^{-1} \mathrm{yr}^{-1}$ for Savijoki. These 
347 totally agricultural area. In spite of this, the annual mean load of Hovi was lower than in the Löytäneenoja

348 catchment where the agricultural area covers $69 \%$. The maximum annual loading varied from $13.6 \mathrm{~kg} \mathrm{ha}^{-1} \mathrm{yr}^{-1}$

349 (2004, Savijoki) to $33.3 \mathrm{~kg} \mathrm{ha}^{-1} \mathrm{yr}^{-1}$ (2000, Hovi). Nitrate-N accounted for 57-72\% of TN in these agricultural

350 catchments. Flow-weighted TN concentration seemed to increase in the Löytäneenoja and Haapajyrä catchments

351 (Fig. 7).

352

353 Fig. 7. Annual loads and flow-weighted concentration of TN and TP in the agricultural catchments.

354

355 In the mixed catchments, the average annual TN load was $3.6 \mathrm{~kg} \mathrm{ha}^{-1} \mathrm{yr}^{-1}$ (Ruunapuro) and $6.4 \mathrm{~kg} \mathrm{ha}^{-1} \mathrm{yr}^{-1}$

356 (Latosuonoja). The flow-weighted TN concentration seemed to increase in the Latosuonoja basin, but the

357 variability between the years was very high (Fig. 8).

358

359 Fig. 8. Annual loads and flow-weighted concentration of TN and TP in the mixed catchments.

360

361

362

363

364

365

366

367

368

369

370

371

372

373

374

375

376

377

378

379

380

381

382

383

384

385
Phosphorus loads in the agricultural catchments

The TP loads were also highest in the agricultural catchments as expected, with average annual loads of $1.34 \mathrm{~kg}$ $\mathrm{ha}^{-1} \mathrm{yr}^{-1}$ for Hovi, $0.46 \mathrm{~kg} \mathrm{ha}^{-1} \mathrm{yr}^{-1}$ for Löytäneenoja, $0.23 \mathrm{~kg} \mathrm{ha}^{-1} \mathrm{yr}^{-1}$ for Haapajyrä and $0.62 \mathrm{~kg} \mathrm{ha}^{-1} \mathrm{yr}^{-1}$ for Savijoki. The maximum estimated annual TP load was $2.75 \mathrm{~kg} \mathrm{ha}^{-1} \mathrm{yr}^{-1}$ (Hovi, 2000). As contrary to TN, no long-term changes in flow-weighted TP concentration could be seen, but year-to-year variability was extremely high at the Hovi catchment. The share of DRP of the TP load was highest (27.5\%) in the Löytäneenoja catchment, while at Haapajyrä it was only 5.9\% (Fig. 7).

\section{Nitrogen loads in the forested catchments}

Fairly low annual average TN loading values were obtained in the forested catchments $\left(1.8 \mathrm{~kg} \mathrm{ha}^{-1} \mathrm{yr}^{-1}\right)$, while $14 \%$ of the TN loads, on average, were obtained in the agricultural catchments $\left(13.1 \mathrm{~kg} \mathrm{ha}^{-1} \mathrm{yr}^{-1}\right)$. In the forested catchments, the average annual TN load varied from 0.6 to $3.0 \mathrm{~kg} \mathrm{ha}^{-1} \mathrm{yr}^{-1}$. The average annual TN loading was lowest in the northern catchments, which was less than the often-used average TN background loading estimate for Finland (1.4 $\mathrm{kg} \mathrm{ha}^{-1} \mathrm{yr}^{-1}$, Mattsson et al. 2003). Flow-weighted TN concentrations seemed to increase in the Teeressuonoja and Huhtisuonoja catchments (Figs. 7 and 9). Nitrate-nitrogen accounted for only $3.6 \%$ of TN in Myllypuro and up to $48 \%$ in Teeressuonoja. The average share $\left(\mathrm{NO}_{3}-\mathrm{N} / \mathrm{TN}\right)$ for all forested catchments was $18 \%$, which was much less than in the agricultural catchments. This means that most of the TN is leached in organic form in these forested catchments (Fig. 9).

Fig. 9. Annual loads and flow-weighted concentration of TN and TP in the forested catchments.

\subsubsection{Phosphorus loads in the forested catchments}

The annual average TP loads in the forested catchments were also at the modest level $\left(0.07 \mathrm{~kg} \mathrm{ha}^{-1} \mathrm{yr}^{-1}\right)$, which is on average only $11 \%$ of the TP loads in the agricultural catchments $\left(0.65 \mathrm{~kg} \mathrm{ha}^{-1} \mathrm{yr}^{-1}\right)$. The TP loads varied 
from 0.02 to $0.11 \mathrm{~kg} \mathrm{ha}^{-1} \mathrm{yr}^{-1}$. Dissolved phosphorus (DRP) accounted for $26 \%$ of TP on average, which is of the same order as in the agricultural Löytäneenoja catchment, but much higher than in all the other agricultural catchments. Flow-weighted TP concentrations and loads seemed to decrease in the Vähä-Askanjoki and Huhtisuonoja catchments (Fig. 9).

Averaged TN, $\mathrm{NO}_{3}-\mathrm{N}$, TP and DRP loads during the periods 1981-1994 and 1995-2010 are given in Table 7 for different catchment types. In 1995 Finland joined the EU and started to implement agri-environmental water protection measures of the FAEP. This means that the first period of 1981-1994 is a reference period when no measures were taken. In agricultural catchments, nitrogen loads, both $\mathrm{TN}$ and $\mathrm{NO}_{3}-\mathrm{N}$, increased from the first to the second period by $10 \%$ and $29 \%$, respectively. However, a small reduction can be seen in TP loads ( $9 \%)$, whereas DRP loads have increased (33\%). The situation in the mixed catchments is ambivalent: in Ruunapuro the water protection measures have had a positive effect while in Latosuonoja nitrogen loads (both $\mathrm{TN}_{\text {and }} \mathrm{NO}_{3}$ $\mathrm{N}$ ) and TP loads have increased. In the forested catchments, the reduction of both TP and DRP loading can be seen in most catchments. TN loads have decreased in Kesselinpuro, Myllypuro and Vähä-Askanjoki, while in Teeressuonoja and Huhtisuonoja they have increased.

Table 7. Total nitrogen $(\mathrm{TN})$, nitrate-nitrogen $\left(\mathrm{NO}_{3}-\mathrm{N}\right)$, total phosphorus (TP) and dissolved reactive phosphorus (DRP) loads ( $\mathrm{kg} \mathrm{ha}^{-1} \mathrm{yr}^{-1}$ ) during 1981-1994 (1987-1994 for phosphorus) and 1995-2010 in the three groups of the studied catchments.

Loads related to percentage of arable land in catchments

We found a connection between the percentage of arable land in a catchment and average nutrient load from it (Fig. 10). Here, the Haapajyrä catchment, which is the only one on acid sulphate soils, was excluded from the analysis due to its specific character (high P retention in acid sulphate soils) discussed earlier by Rekolainen (1989) and Vuorenmaa et al. (2002).

Fig. 10. Relationships between percentage of arable land in 11 study catchments and average $\mathrm{TN}, \mathrm{NO}_{3}-\mathrm{N}, \mathrm{TP}$ and DRP loads. $95 \%$ confidence limits are also shown.

Percentage of arable land explained $90 \%$ of the variability of TP losses and $95 \%$ of the TN losses, respectively. From these equations (Fig. 10), we estimated the average background losses, including also forestry and other sources, as follows: for TP $0.04 \mathrm{~kg} \mathrm{ha}^{-1} \mathrm{yr}^{-1}$, for DRP $0.02 \mathrm{~kg} \mathrm{ha}^{-1} \mathrm{yr}^{-1}$, for TN $1.85 \mathrm{~kg} \mathrm{ha}^{-1} \mathrm{yr}^{-1}$ and for $\mathrm{NO}_{3}-\mathrm{N} 0.65$ $\mathrm{kg} \mathrm{ha}^{-1} \mathrm{yr}^{-1}$.

The specific agricultural loads can be assessed from the equations in Fig. 10 (when the share of arable land is set to $100 \%$ ). Then the agricultural loads are $1.1 \mathrm{~kg} \mathrm{ha}^{-1} \mathrm{yr}^{-1}$ for TP, $0.18 \mathrm{~kg} \mathrm{ha}^{-1} \mathrm{yr}^{-1}$ for DRP, $15.5 \mathrm{~kg} \mathrm{ha}^{-1} \mathrm{yr}^{-1}$ for TN and $11.1 \mathrm{~kg} \mathrm{ha}^{-1} \mathrm{yr}^{-1}$ for $\mathrm{NO}_{3}-\mathrm{N}$. These specific agricultural loads were extrapolated to average agricultural nutrient loads in surface waters on a national scale. Here, the specific loading values for 1981-1995 are taken from Vuorenmaa et al. (2002), and the following years are based on this study. As shown in Table 8, the agricultural land area in 1996-2000 is smaller than before, mainly due to the fact that many small farms went out 
of business after Finland joined the EU in 1995. Recently, the area of used agricultural land has risen again due to the increased renting of agricultural land, but even at present, the total area is not at the same level that it was in 1981-1994. The range in total TN loading to surface waters varies between 34,000-37,000 $\mathrm{t} \mathrm{yr}^{-1}$ (Table 8) and

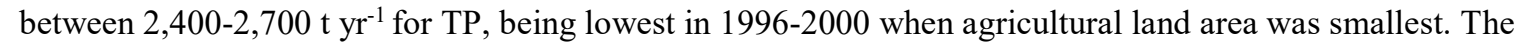
estimated specific load value used in calculations increased by $0.5 \mathrm{~kg} \mathrm{ha}^{-1} \mathrm{yr}^{-1}$ for TN for the latter half (from 1996 onwards) and remained the same for TP.

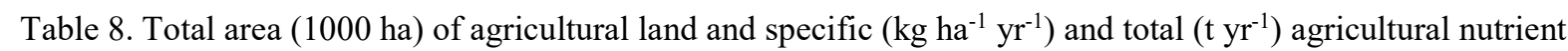
loads to surface waters in Finland in six consecutive five-year periods.

\section{Trend analysis}

Statistically significant decreasing runoff trends in 1981-2010 were found in the Löytäneenoja (21), Ruunapuro (71) and Laanioja (121) catchments. In Ruunapuro, the decrease occurred mostly in autumn, while in Laanioja the downward trend was due to the strongly declined winter runoff (Table 9). Due to a couple of wet years experienced in Finland in the early 1980s, the runoff trends starting from 1981 were generally declining. An exception to this was the Myllypuro (103) catchment, where the winter-time runoff has clearly increased although the total trend is not statistically significant (Table 9).

Table 9. Trends of runoff in the studied catchments during 1981-2010. Dark grey cells denote upward and light grey cells downward trend with $* * *=$ strong, ${ }^{* *}=$ intermediate or $*=$ weak statistical significance. Empty cell $=$ no statistically significant trend.

As for TP concentrations, the trends in 1987-2011 were mostly decreasing (Table 10). The strongest downward trends were found in the eastern and forested catchments of Huhtisuonoja (44) and Kesselinpuro (51), both of which showed total P decline particularly in spring, with Huhtisuonoja also showing a decline in autumn. Statistically significant downward total P trends were also found in the northern Vähä-Askanjoki (114) catchment and in the agricultural Savijoki (22) and Haapajyrä (81) catchments. In terms of DRP concentrations, the trends in non-agricultural catchments were by and large in line with those of TP, but the statistical significance was generally stronger (Table 10). Except for three agricultural catchments and one mixed catchment (Ruunapuro 71), all DRP trends were significantly decreasing, mostly in forested catchments. Significantly upward DRP trends were found in the agricultural Hovi (11) and Löytäneenoja (21) catchments, both of which had increasing trends occurring in autumn (Table 11).

Table 10. Trends of total phosphorus concentrations in the studied catchments during 1987-2011. Dark grey cells denote upward and light grey cells downward trend with $* * *=$ strong, $* *=$ intermediate or $*=$ weak statistical significance. Empty cell $=$ no statistically significant trend. 
Table 11. Trends of dissolved reactive phosphorus concentrations in the studied catchments during 1987-2011. Dark grey cells denote upward and light grey cells downward trend with $* * *=$ strong, $* *=$ intermediate or $*=$ weak statistical significance. Empty cell = no statistically significant trend.

Total $\mathrm{N}$ concentrations in 1981-2011 showed predominantly increasing trends (Table 12). In agricultural catchments there was an intermediately significant upward trend in Löytäneenoja (21) and a strongly significant upward trend in Haapajyrä (81). The forested Huhtisuonoja (44) catchment also showed a strongly increasing trend of total $\mathrm{N}$ concentration. The only statistically significant decreasing total $\mathrm{N}$ trend was detected in the northern Vähä-Askanjoki (114) site (Table 12).

Table 12. Trends of total nitrogen concentrations in the studied catchments during 1981-2011. Dark grey cells denote upward and light grey cells downward trend with $* * *=$ strong, $* *=$ intermediate or $*=$ weak statistical significance. Empty cell = no statistically significant trend.

In terms of $\mathrm{NO}_{3}-\mathrm{N}$ concentrations, the trend in Haapajyrä (81) was strongly increasing. Also in the southern Löytäneenoja (21) and Teeressuonoja (14) catchments intermediately significant upward trends of $\mathrm{NO}_{3}-\mathrm{N}$ concentrations were found. Strongly significant decreasing $\mathrm{NO}_{3}-\mathrm{N}$ trends were detected in the northernmost Vähä-Askanjoki (114) and Laanioja (121) catchments. Seasonally, the upward $\mathrm{NO}_{3}-\mathrm{N}$ concentration trends seemed to be mostly due to the increases during the period from September to December. Meanwhile, in the downward $\mathrm{NO}_{3}-\mathrm{N}$ trends detected in Vähä-Askanjoki and Laanioja, both spring and autumn periods played a role (Table 13).

Table 13. Trends of $\mathrm{NO}_{3}$ - nitrogen concentrations in the studied catchments during 1981-2011. Dark grey cells denote upward and light grey cells downward trend with $* * *=$ strong, $* *=$ intermediate or $*=$ weak statistical significance. Empty cell = no statistically significant trend.

\section{Continuous water quality monitoring - the Savijoki case}

The produced calibration equations (Table 4) were used to convert raw turbidity and $\mathrm{NO}_{3}-\mathrm{N}_{\text {concentration data }}$ into TP and TN concentrations. First, the calibrated automatic turbidity data was compared with the corresponding laboratory measurements (Fig. 11). Even though the annual dynamics in turbidity was wellcaptured with the on-line automatic sensor, there was more difference between measured and calculated data during 2012 and especially during 2013 than in the beginning of the monitoring period. If a 10 per cent deviation $(<|6.7|$ FTU) from the mean concentration (2010-2013) is used as a criterion for "good data," 62 per cent of the data passed the test. If the criterion is set to 20 per cent $(<|13.4|$ FTU), 83 per cent of the data could be classified as good. For $\mathrm{NO}_{3}-\mathrm{N}$, the visual fit between measured and calculated data was even better than in the case of turbidity, but here the 10 per cent criterion $\left(<|0.138| \mathrm{mg} \mathrm{l}^{-1}\right)$ gave only 40 per cent "good data," whereas the 20 per cent criterion gave 67 per cent "good data." 
504 Fig. 11. Hourly time series of the calibrated turbidity measured by optical sensors (NTU) together with turbidity

505 analysed from water samples. The difference between measured and calculated values is shown with open

506 circles.

508 Monthly TN and TP loads calculated with the periodic method and with the continuous water quality

509 measurements (1 hour frequency) are presented in Fig. 12. Most loading occurred either during the spring

510 snowmelt period or during late autumn, with substantial variability between the years. For both nutrients, the

511 greatest difference was observed during the high flow peaks. In 2010, the TN peak load was underestimated

512 with the Period method (PeriodMeth), while in 2011 and 2012, the peak load was overestimated with it. The

513 Continuous measurements -method (ContinMeth) is assumed to give the most correct load estimate. For TP

514 loads, the difference was greatest in 2010. The average annual loads for TN and TP are presented in Table 14.

515

516 Fig.12. Monthly TN and TP loads in the Savijoki catchment in 2010-2012 as calculated on the bases of (i)

517 automatic monitoring and (ii) daily flow and water sampling data (load calculated with the periodic method).

518

519 Table 14. Annual average loadings $\left(\mathrm{kg} \mathrm{ha}^{-1} \mathrm{yr}^{-1}\right)$ for total nitrogen (TN) and total phosphorus (TP) in the Savijoki

520 catchment as calculated with period method (PeriodMeth) and with 1-hour continuous water quality data

521 (ContinMeth).

522

523

524

525

526

527

528

529

530

531

532

533

534

535

536

537

538

539

540

541

542

543

\section{Discussion}

\section{Agricultural and mixed catchments}

High differences were observed in nutrient concentrations between the agricultural catchments, explained mostly by varying share of arable land within the catchments. Other contributing factors include soil types, different agricultural practices, the amount of use and efficiency of water protection measures, and hydrometeorological variability. In mixed catchments the nutrient concentrations were lower than in the agricultural catchments but higher than in the forested catchments.

In Finland, the major share of nutrient loading has originated from agriculture for decades (Rekolainen et al. 1997; Vuorenmaa et al. 2002), and the common pattern remains the same. The average TN load in agriculturedominated catchments was $13.3 \mathrm{~kg} \mathrm{ha}^{-1} \mathrm{yr}^{-1}$, i.e. 9 times higher than the average background $\mathrm{N}$ loss value of 1.40 $\mathrm{kg} \mathrm{ha}^{-1} \mathrm{yr}^{-1}$. Respectively, the average $\mathrm{P}$ load in the four agricultural catchments here was $0.66 \mathrm{~kg} \mathrm{ha}^{-1} \mathrm{yr}^{-1}$, i.e. on average 12 times higher than the most often used background $\mathrm{P}$ loss value for Finland $\left(0.054 \mathrm{~kg} \mathrm{ha}^{-1} \mathrm{yr}^{-1} \mathrm{based}\right.$ on 21 natural-state catchments, Mattsson et al. 2003). Spatially, a mosaic of a large number of crops, several different agricultural practices and water protection measures are used in agriculture. Temporally, fertilisation and ploughing are common practices almost every year, with year-to-year variability. 
544 Statistically significant decreasing runoff trends in 1981-2010 were found in Löytäneenoja, which could partly

545 explain the increase in total $\mathrm{N}$ and $\mathrm{NO}_{3}-\mathrm{N}$ concentrations in the summer period, but not during autumn or

546 wintertime.

547

548 There was no increase in TP concentrations. The increase in DRP concentrations in some areas can be a result of

549 the increased non-plough cultivation and direct sowing, which have taken place in almost two thirds of the

550 earlier autumn-ploughed fields. Gonzales-Inca et al. (2016) found increasing trends in concentrations and loads

551 of dissolved reactive phosphorus (DRP) and decreasing trends in TSS in the agricultural Yläneenjoki river

552 basin: these trends might be linked to the current effort of agricultural soil erosion reduction. Decreased tillage

553 or no-tillage methods increased in the Yläneenjoki catchment from $17 \%$ to $39 \%$ of arable land area between

5542000 and 2010 (Aakkula and Leppänen 2014). Several other studies carried out in Finland found that the

555 mobilisation of DRP increases in areas with reduced tillage depth or no-till (Koskiaho et al. 2002; Uusitalo et al.

556 2007), and in vegetated buffer zones (Uusi-Kämppä and Jauhiainen 2010). It is also notable that the average

557 fertilisation rates have decreased from $40 \mathrm{~kg} \mathrm{P} \mathrm{ha}^{-1}$ to $8 \mathrm{~kg} \mathrm{P} \mathrm{ha}^{-1}$ (see Fig. 2) and, in addition, farmers have put

558 many other water protection measures, e.g. constructed wetlands and controlled drainage, into operation.

559 Nevertheless, TP concentration decreased in only half of the catchments.

560

561 In Estonia, Iital et al. (2013) investigated temporal dynamics in N concentrations and losses in small catchments

562 for the period 1992-2011. The studied areas represented various agricultural production areas. The Mann-

563 Kendall trend test revealed one (of eight) statistically significant upward trend in TN concentration. A less

564 significant upward trend in TN was also noted in two other streams. None of the streams showed a statistically

565 significant downward trend in nitrogen concentration, correspondingly as in our study. Iital et al. (2013) also

566 conclude that a proper understanding of nutrient loss processes at the small catchment scale requires updated

567 data on actual agricultural practices. In southern Europe environmental land use conflicts within catchments

568 have recently been recognized as major cause of soil and nutrient losses to rivers (Pacheco et al. 2014; Valle

569 Junior et al. 2014).

570

571 Kyllmar et al. (2006) investigated 27 small agricultural catchments in Sweden for 9-14-year study periods

572 starting in the late 1980s. Significant downward trends were revealed for $\mathrm{NO}_{3}-\mathrm{N}$, DRP and particulate P (PP) for

573 seven, eight and three catchments (out of 24 catchments), respectively, whereas upward trends were revealed for

$574 \mathrm{NO}_{3}-\mathrm{N}$ and PP for only one and two catchments, respectively. The downward trend for $\mathrm{NO}_{3}-\mathrm{N}$ was explained by

575 lesser amounts of manure applied, and a change in season for manure application and crop distribution, i.e. more

576 winter-sown crops and fallow. Significant downward trends were also detected for DRP. Kyllmar et al. (2006)

577 also concluded that the measures undertaken so far show - in general - a better response for $\mathrm{NO}_{3}-\mathrm{N}$ and DRP, as

578 compared to PP. They also argued that a more thorough evaluation of agricultural data is needed to fully explain

579 trends and non-trends in time series. However, in that Swedish study, the measures seem to respond better as

580 downward trends in $\mathrm{NO}_{3}-\mathrm{N}$ and DRP than in Finland. In Finland, more erosion control measures have been

581 implemented. 
583 In Denmark, the trends have been somewhat different. Windolf et al. (2012) conclude that the TN load to ten

584 estuaries (catchments covering 35\% of the Danish land area) has decreased by 39\% during the period 1990-

585 2009. They also report an 18-55\% reduction for the mean flow-weighted TN concentrations in inlet to estuaries.

586 Targeted and catchment-specific measures are the most cost-efficient way to achieve good chemical quality in

587 estuaries (Windolf et al. 2012). In Finland, the implementation of measures has not been well-targeted and

588 widely applied so far, which might explain rather limited improvements in water quality. On the other hand, the

589 concentration levels have been and are evidently higher in Danish water bodies than in the Finnish ones (see

590 EEA Wise database), which gives more possibilities for load reductions in Denmark than in Finland.

591

592

593

594 The efficiency of the water protection measures in agriculture is generally assessed at the field plot scale and the

595 measures are then ranked according to different practices and techniques (e.g. Puustinen et al. 2007; Uusi-

596 Kämppä et al. 1998; Ekholm et al. 2011; Salomon and Sundberg 2012). This is normally a good starting point

597 for implementing the measures. However, from the perspective of the river basin scale, the scaling issues

598 should be taken into account: what assortment and volume of measures will give noticeable impacts even at the

599 outlet of the river basin?

600

601 Some notable and wide-ranging changes took place in Finnish agriculture after Finland joined the EU in 1995.

602 The decrease in the use of fertilisers (Fig. 2) has led to reduced balances of nitrogen and phosphorus, the

603 reduction being $35 \%$ and 60\%, respectively, from the earlier levels (Aakkula \& Leppänen, 2014). The autumnal

604 ploughed area has declined by nearly one third from the earlier levels. Autumnal ploughing has been replaced

605 by reduced tillage, wintertime stubble or direct sowing. In total, the measures practicable at each field plot - i.e.

606 in very large scales - will therefore be potentially efficient in nutrient reduction efforts. At the Hovi catchment

607 of this study, the tillage practices vary from year to year, but the major change was clear: autumn ploughing has

608 decreased from $100 \%$ in $1981-1987$ to $0-30 \%$ in $2005-2010$, replaced by reduced tillage methods. This may

609 have had a stabilising effect on nutrient loading: the nutrient concentrations have been stable (not increasing),

610 but for DRP there is indication of increasing concentration trends, particularly in autumn (Table 9) - probably

611 due to the increased reduced tillage practices.

612

613 The question remains why there are only a few significant downward trends especially for nitrogen at the

614 catchment scale despite all the efforts made. It is obvious that the number of efficient measures, in particular for

615 nitrogen, is still too modest. Factors related to climate change probably also contribute to another direction (e.g.

616 Blombäck et al. 2012; Børgesen and Olesen 2011; Hägg et al. 2014). In Finland, the most wide-ranging

617 measure, i.e. wintertime vegetation cover, seems to work for PP, but there are signs of mobilisation, and parallel

618 increases in DRP concentrations and loads (e.g. Uusitalo et al. 2007; Gonzales-Inca et al. 2016).

619

620 Due to these aspects, we cannot say that the implemented water protection measures have been successful

621 enough to cut down the agricultural loading, even though the efficiency of many measures is shown at the field plot level. There are some positive signs of decreases in total P loading, but not for N loading. 
Forested catchments

626

High variability was observed in nutrient concentrations between the forested catchments, explained by i) different intensity of forestry practices (drainage and supplementary drainage, cuttings, fertilisations etc.) over the years, ii) by natural characteristics, and iii) by hydrometeorological variation. The most obvious changes have been due to the changes in forestry, with some examples given below.

630

Forest loads - average levels and as compared with background loads

The average TN load here, $1.75 \mathrm{~kg} \mathrm{ha}^{-1} \mathrm{yr}^{-1}$, was about the same as an earlier estimate for the average TN load for managed forests, $1.83 \mathrm{~kg} \mathrm{ha}^{-1} \mathrm{yr}^{-1}$ by Kortelainen \& Saukkonen (1998). The average TP load, $0.07 \mathrm{~kg} \mathrm{ha}^{-1} \mathrm{yr}^{-1}$, was clearly lower (30\%) than the earlier estimate of $0.10 \mathrm{~kg} \mathrm{ha}^{-1} \mathrm{yr}^{-1}$ by Kortelainen \& Saukkonen (1998). This means that TP loading from managed forests seems to have decreased in large areas, most probably due to decreased forest fertilisation, discussed more in detail below.

Average TP load in the six managed forested catchments was on average 1.3 times higher than the most often used background $\mathrm{P}$ loss value for Finland, $0.054 \mathrm{~kg} \mathrm{ha}^{-1} \mathrm{yr}^{-1}$ (Mattsson et al. 2003). Respectively, average $\mathrm{N}$ load was $1.75 \mathrm{~kg} \mathrm{ha}^{-1} \mathrm{yr}^{-1}$, i.e. 1.3 times higher than the average background $\mathrm{N}$ loss value of $1.40 \mathrm{~kg} \mathrm{ha}^{-1} \mathrm{yr}^{-1}$. This means that forest management increases loading from forests by one third, on average. Spatially, the mosaic of a huge number of treatment areas is typical in forestry. Temporally, treatment areas vary from year to year, and the impacts of a single treatment may last from a couple of years to $>10$ years.

648 The TN concentrations increased in most of the forested sites. They increased significantly in Huhtisuonoja and

649 Myllypuro with no changes in $\mathrm{NO}_{3}-\mathrm{N}$, which means that dissolved organic $\mathrm{N}$ concentrations (DON) are

650 increasing. In these catchments the percentage of organic peat soils is relatively high, i.e. $45 \%$ and $27 \%$,

651 respectively. This DON increase seems to be related to increasing trends of winter flows (increasing trends in

652 flow from November to January) particularly in Myllypuro. In Huhtisuonoja there is an increasing, but not 653 statistically significant, trend in annual flow in 1987-2010. Correspondingly, increasing trends in winter flow

654 were detected in the northern, forest and peatland -dominated river basin, together with increasing trends in

655 TON (total organic N) concentrations in autumn - mid-winter (Lepistö et al, 2008). in 1960-1992 (Kortelainen and Saukkonen 1998). According to Keinänen (2013), only 2.1\% of Huhtisuonoja and 5\% of Myllypuro remained undrained in 2008. The delivery of terrestrial DON to aquatic systems depends on production/decomposition rates, solubility and the availability of hydrological transport. The leaching of organic matter, particularly DOC but also DON, typically increases strongly with peatland proportion. Pellerin et al. (2004) found that $79 \%$ of the variance in

664 DON concentrations in streams and rivers in the northeastern U.S. was explained by the percentage of wetlands 
in a catchment. According to a recent study in Finnish watersheds, wetlands were found to play an important role: most of the TOC and TON were transported during the high flow following the spring snowmelt and during autumn rainfall (Mattsson et al. 2015).

668

669

670

671

672

673

674

675

676

677

678

679

680

681

682

683

684

685

686

687

688

689

690

691

692

693

694

695

696

697

698

699

700

701

702

703

704

705

First time drainage works were ending in Finland in the early 1990s (Forest statistical yearbook). Supplementary drainage (ditch maintenance) areas increased all through the 1990s and 2000s on a national scale, and also in the research catchments of Huhtisuonoja and Myllypuro, but the catchment-scale data of these areas is unfortunately not available. Increasing winter flows in these drained, forested catchments most obviously increase leaching losses of organic matter, detected here as increasing trends in DON. In many of these forested catchments studied by Keinänen (2013), particularly in Huhtisuonoja, the clearly increased concentrations of TOC have been detected.

On the other hand, in the southern Teeressuonoja site, an increase was detected in both total $\mathrm{N}$ and $\mathrm{NO}_{3}-\mathrm{N}$ concentrations. The increase in $\mathrm{NO}_{3}-\mathrm{N}$ relates probably to increases in nitrification in catchment soils due to several performed clear-cuttings in 1985-2001 during our monitoring period. It has been stated that considerable nitrification in coniferous forests is possible after clear-cutting (e.g. Tamm et al. 1974), when plant nutrient uptake is decreased and $\mathrm{pH}$ is increased. Together, clear-cuttings cover a total of $28 \%$ of the Teeressuonoja catchment (Keinänen 2013).

For TP concentrations in forested catchments, the trends in 1987-2011 were mostly decreasing, and significantly so in three of the six catchments, while dissolved DRP concentrations decreased significantly in all forested catchments. At the same time P fertilisation in Finnish forests decreased significantly. The average fertilised forest areas in Finland dropped to one tenth: from 70,000 ha/year in the late 1980s (1986-1990) to 7,000 ha/year in the early 1990s (1991-1995), remaining relatively low during the late 1990s and 2000s (Fig. 2) (Metla Forest Statistical Yearbook 2014).

$\mathrm{P}$ fertilisation plays a significant role with impacts on $\mathrm{P}$ losses: the application history of $\mathrm{P}$ fertilisation was detected as the most important predictor for the spatial variation in total $\mathrm{P}$ leaching from 22 small, managed and forested catchments in Finland (Kortelainen and Saukkonen, 1998). Fertiliser P along with potassium (K) is applied to peatland forests to increase their productivity. Leaching is typically highest in the first and second year after fertilization, and $\mathrm{P}$ concentrations in the outflow water may remain at a higher level than before fertilising for several years, even for over a decade (Ahtiainen and Huttunen 1999; Joensuu et al. 2001;

Väänänen 2008).

This decrease of $\mathrm{P}$ fertilisation is very probably the main reason for decreased $\mathrm{P}$ concentration trends (total $\mathrm{P}$ and DRP) in most of the forested sites. At Huhtisuonoja, specifically, extensive P fertilisation of $70 \%$ of the total area of peatlands of the catchment took place in 1985-1986, just before the monitoring period (Pietiläinen and Rekolainen 1991). This can be clearly seen in high detected P concentration levels of 80-90 $\mu \mathrm{g} \mathrm{l}^{-1}$ in 19871989 (Fig. 9), with gradually decreasing concentrations and losses after that. Both total P and DRP concentrations had statistically significant decreasing trends (Tables 9, 10). 


\subsection{Agricultural load on a national scale}

Strong connections were found between the percentage of arable land in a catchment and the average nutrient load from it (Fig. 10). The percentage of arable land explained $90 \%$ of the variability of TP losses and $95 \%$ of the TN losses, respectively. The specific agricultural loads were extrapolated to average agricultural nutrient loads on a national scale. The range in estimated total TN loading varies between $34000-37000 \mathrm{t} \mathrm{y}^{-1}$ (Table 8) and between 2 400-2 $700 \mathrm{t} \mathrm{y}^{-1}$ for TP. The agricultural land area in 2000-2010 was smaller than before (19811995), which was mainly due to the decrease in the number of small farms. This study suggests that the specific nutrient loading is a bit higher for TN than earlier (Vuorenmaa et al. 2002) but is at the same level for TP. The new load estimates are of the same order than those reported earlier and variation is mostly due to changes in agricultural area.

\section{Conclusions}

Total $\mathrm{N}$ concentrations increased in two of the four agricultural sites in 1981-2010. They increased significantly in Löytäneenoja and Haapajyrä with concomitant change in $\mathrm{NO}_{3}-\mathrm{N}$. Statistically significant decreasing runoff trends in 1981-2010 were found in three of the twelve sites and only one increasing trend was found in Myllypuro. The TN concentrations increased in most of the forested sites. Total $\mathrm{N}$ concentrations increased significantly in two forested sites with no changes in $\mathrm{NO}_{3}-\mathrm{N}$, which means that organic $\mathrm{N}$ concentrations (DON) are increasing. Increased winter temperatures seem to contribute to increasing mineralization and increasing organic-N losses, and play a role in $\mathrm{N}$ cycles of both agricultural and forested catchments.

For TP concentrations, the trends in 1987-2010 were decreasing in two of the four agricultural catchments, while DRP concentrations decreased in one of the four catchments and increased in two others. There was no increase in TP concentrations. The increase in DRP concentration may be a result of the increased non-plough cultivation and direct sowing which have taken place in almost two thirds of earlier autumn-ploughed field areas. For TP concentrations in forested catchments, the trends in 1987-2011 were mostly decreasing, and significantly so in three of the six catchments, while DRP concentrations decreased significantly in all forested catchments. At the same time P fertilization areas in Finnish forests decreased significantly, which has obviously contributed to decreasing concentrations and loads.

Why can only a few significant downward trends be detected, especially for nitrogen, at the agricultural catchment scale despite all the efforts made? It is obvious that the extent of efficient measures, in particular for nitrogen, is still too modest. In Finland, the most wide-ranging measure, i.e. wintertime vegetation cover, seems to work for PP, but there are signs of parallel DRP load increases. More efforts with wide-ranging and carefully targeted implementation of water protection measures are needed in order to get visible impacts on the catchment scale.

\section{References}


745 Aakkula, J. \& Leppänen, J. (Eds.) 2014. Maatalouden ympäristötuen vaikuttavuuden seurantatutkimus

746 (MYTVAS 3). Maa- ja metsätalousministeriö 3/2014, 265 p. [In Finnish].

748 Ahtiainen, M. \& Huttunen, P. (1999). Long-term effects of forestry managements on water quality and loading

749 in brooks. Boreal Environment Research 4: 101-114.

750

751 Berninger, K., Koskiaho, J. \& Tattari, S. (2012). Constructed wetlands in Finnish agricultural environments :

752 balancing between effective water protection, multi-functionality and socio-economy. Journal of Water and

753 Land Development 17: 19-29.

754

755 Blombäck, K., Børgesen, C.D., Eckersten, H., Giełczewski, M., Piniewski, M., Sundin, S., Tattari, S. \&

756 Väisänen, S. (2012). Productive agriculture adapted to reduced nutrient losses in future climate - Model and

757 stakeholder based scenarios of Baltic Sea catchments. Baltic COMPASS-report.

758 http://www.balticcompass.org/ blog/Project Reports/post/future-nutrient-load-scenarios/. Accessed 1

759 June 2016.

760

761

Børgesen, C.D. \& Olesen, J. (2011). A probabilistic assessment of climate change impacts on yield and nitrogen

762 leaching from winter wheat in Denmark. Natural hazards and earth system sciences 11(9): 2541-2553.

763

764 Collins, A.L., Zhang, Y.S., Winter, M., Inman, A., Jones, J.I., Johnes, P.J., Cleasby, W., Vrain, E., Lovett, A., Noble, L. (2016). Tackling agricultural diffuse pollution: What might uptake of farmer-preferred measures deliver for emissions to water and air? Science of Total Environment, 547:269-281.

767

768

Ekholm, P., Jaakkola, E., Kiirikki, M., Lahti, K., Lehtoranta, J., Mäkelä, V., Näykki, T., Pietola, L., Tattari, S., Valkama, P., Vesikko, L. \& Väisänen, S. (2011). The effect of gypsum on phosphorus losses at the catchment scale. Finnish Environment 33.

Foy, R. H. \& Withers, P. J. A. (1995). The contribution of agricultural phosphorus to eutrophication, Fertil. Soc., Proc. no. 365, 32 pp. from agricultural catchments of Yläneenjoki and Pyhäjoki, SW Finland. Boreal Environment Research 21 (in press).

Granlund, K., Räike, A., Ekholm, P., Rankinen, K. \& Rekolainen, S. (2005). Assessment of water protection targets for agricultural nutrient loading in Finland. Journal of Hydrology 304(1-4): 251-260. 
786 Helcom. (2014). The fourth Baltic Sea pollution load compilation (PLC 4). Baltic Sea Environment Proceedings No. 93

Hirsch, R.M. \& Slack, J.R. (1984). A nonparametric trend test for seasonal data with serial dependence. Water

Hägg, H.E., Lyon, S.W., Wällstedt, T., Mörth, C.M., Claremar, B. \& Humborg, C. (2014). Future nutrient load scenarios for the Baltic Sea due to climate and lifestyle changes. Ambio 43(3): 337-351.

794

Iital, A., Klõga, M., Pihlak, M., Pachel, K., Zahharov, A. \& Loigu, E. (2013). Nitrogen content and trends in

IPCC (2013). Climate Change 2013: The Physical Science Basis. Contribution of Working Group I to the Fifth Assessment Report of the Intergovernmental Panel on Climate Change [Stocker, T.F., Qin, D., Plattner, G.-K., Tignor, M., Allen, S.K., Boschung, J., Nauels, A., Xia, Y., Bex, V. and Midgley, P.M. (Eds)]. Cambridge University Press, Cambridge, United Kingdom and New York, NY, USA.

802

803

Joensuu, S., Ahti, E. \& Vuollekoski, M. (2001). Long-term effects of maintaining ditch networks on runoff

804 water quality. Kunnostusojituksen pitkän ajan vaikutus valumaveden ominaisuuksiin. Suo - Mires and Peat

805 52(1): 17-28. [In Finnish].

806

807 Kauppila, P. \& Koskiaho, J. (2003). Evaluation of annual loads of nutrients and suspended solids in Baltic rivers. Nordic Hydrology 34: 203-220.

809

810 Keinänen, H. (2013). Ilmastovaihteluiden ja metsätaloustoimenpiteiden vaikutukset pienten metsäisten valuma-

811 alueiden veden fysikaalis-kemialliseen laatuun. Pro gradu. Helsingin yliopisto. Geotieteiden ja maantieteen 812 laitos. 84 p. [In Finnish].

813

814 Korhonen, J. \& Kuusisto, E. (2010). Long-term changes in the discharge regime in Finland. Hydrology 815 Research 41(3-4): 253-268.

816

817 Kortelainen, P. \& Saukkonen, S. (1998). Leaching of nutrients, organic carbon and iron from Finnish forestry 818 land. Water, Air and Soil Pollution 105: 239-250.

819

820 Koskiaho, J., Kivisaari, S., Vermeulen, S., Kauppila, R., Kallio, K. \& Puustinen, M. (2002). Reduced tillage: 821 Influence on erosion and nutrient losses in a clayey field in southern Finland. Agricultural and Food Science in 822 Finland 11(1): 37-50. 
824 Koskiaho, J., Lepistö, A., Tattari, S. \& Kirkkala, T. (2010). On-line measurements provide more accurate 825 estimates of nutrient loading: a case of the Yläneenjoki river basin, southwest Finland. Water science and technology 62(1): 115-122. http://www.iwaponline.com/wst/06201/wst062010115.htm.

827

828 Kronvang, B., Grant, R., Larsen, S. E., Svendsen, L. M. \& Kristensen, P. (1995). Non-point-source nutrient 829 losses to the aquatic environment in Denmark: impact of agriculture, Mar. Freshw. Res. 46: 167-177.

830

831 Kyllmar, K., Carlsson, C., Gustafson, A., Ulén, B. \& Johnsson, H. (2006). Nutrient trends from small

832 agricultural catchments in Sweden. Characterisation and trends. Agriculture, Ecosystems and Environment 115: $833 \quad 15-26$

834

835 Kyllmar, K., Bechmann, M., Deelstra, J., Iital, A., Blicher-Mathiesen, G., Jansons, V., Koskiaho, J., Povilaitis, 836 A. (2014). Long-term monitoring of nutrient losses from agricultural catchments in the Nordic-Baltic region 837 A discussion of methods, uncertainties and future needs. Agriculture, Ecosystems \& Environment 198: 4-12.

838

839 Lepistö, A., Granlund, K., Kortelainen, P. \& Räike, A. (2006). Nitrogen in river basins: Sources, retention in the 840 surface waters and peatlands, and fluxes to estuaries in Finland. Science of the Total Environment 365(1-3): $841238-259$.

842 Lepistö. A., Kortelainen, P. \& Mattsson, T. (2008). Increased organic C and N leaching in a northern boreal river basin in Finland. Global Biogeochemical Cycles, doi:10.1029/2007GB003175.

845

846 Linjama, J., Puustinen, M., Koskiaho, J., Tattari, S., Kotilainen, H. \& Granlund, K. (2009). Implementation of 847 automatic sensors for continuous monitoring of runoff quantity and quality in small catchments. Agricultural 848 and Food Science 18: 417-427.

849

850 Linjama, J., Järvinen, J. \& Kivinen, Y. (2012). Runoff. In: Korhonen, J. and Haavanlammi, E. (Eds.) Hydrological Yearbook 2006-2010. Suomen Ympäristö 8.

852

853 Lääne, A., Pitkänen, H., Arheimer, B., Behrendt, H., Jarosinski, W., Sarmite, L., Pachel, K., Shekhovtsov, A., 854 Svendsen, L.M. \& Valatka, S. (2002). Evaluation of the implementation of the 1988 Ministerial Declaration regarding nutrient load reductions in the Baltic Sea catchment area. Finnish Environment Institute. The Finnish Environment no. 524, 195 pp.

Mattsson, T., Finer, L., Kortelainen, P. \& Sallantaus, T. (2003). Brook water quality and background leaching from unmanaged forested catchments in Finland. Water, Air, and Soil Pollution 147: 275-297.

861 Mattsson, T., Kortelainen, P., Räike, A., Lepistö, A. \& Thomas, D.N. (2015). Spatial and temporal variability of organic $\mathrm{C}$ and $\mathrm{N}$ concentrations and export from 30 boreal rivers induced by land use and climate. Science of the Total Environment 508: 145-154. 
865

866

867

868

869

870

871

872

873

874

875

876

877

878

879

880

881

882

883

884

885

886

887

888

889

890

891

892

893

894

895

896

897

898

899

900

901

902

Metla Forest Statistical Yearbook, 2014. http://www.metla.fi/julkaisut/metsatilastollinenvsk/index-en.htm $(13.7 .2015)$.

Ministry of Agriculture and Forestry, (2004). Horisontaalisen maaseudun kehittämisohjelman väliarviointi. Manner Suomi. [In Finnish]. MMM:n julkaisuja 1. Maa- ja metsätalousministeriö, Helsinki. 272 p.

Näykki, T., Kyröläinen, H., Witick, A., Mäkinen, I., Pehkonen, R., Väisänen, T., Sainio, P. \& Luotola, M. (2013). Quality recommendations for data entered into the environmental administration's water quality registers: Qualification limits, measurement uncertainties, storage times and methods associated with analytes determined for water. [Abstract in English]. Environmental Administration Guidelines 4, 54 p.

Pacheco, F.A.L., Varandas, S.G.P., Sanches Fernandes, L.F., Valle Junior, R.F. 2014. Soil losses in rural watersheds with environmental land use conflicts. Science of Total Environment 485:110-120.

Pacheco, F.A.L. and Sanches Fernandes, L.F. 2016. Environmental land use conflicts in catchments: A major cause of amplified nitrate in river water. Science of the Total Environment 548-549:173-188.

Pellerin, B. A., Wollheim, W. M., Hopkinson, C. S., McDowell, W. H., Williams, M. R., Vorosmarty, C. J. \& Daley, M. L. (2004). Role of developed land use and wetlands on hydrologic dissolved organic nitrogen losses from northeastern US watersheds. Limnol. Oceanogr. 49: 910-918.

Pietiläinen, O-P. \& Rekolainen, S. (1991). Dissolved reactive and total phosphorus load from agricultural and forested basins to surface waters in Finland. Aqua Fennica 21:127-136.

Puustinen, M., Tattari, S., Koskiaho, J. \& Linjama, J. (2007). Influence of seasonal and annual hydrological variations on erosion and phosphorus transport from arable areas in Finland. Soil \& Tillage Research 93: 44-55.

Rekolainen, S. (1989). Phosphorus and nitrogen load from forest and agricultural areas in Finland. Aqua Fennica 19: 95-107.

Rekolainen, S., Ekholm, P., Ulén, B. \& Gustafsson, A. (1997). Phosphorus losses from agriculture to surface waters in the Nordic countries. In: Tunney, H., Carton, O.T., Brookes, P.C. \& Johnston, A.E. (Eds.), Phosphorus losses from soil to water (pp. 77-93). CAB International, Wallingford.

Rocha, J., Roebeling, P., Rial-Rivas, M.E. (2015). Assessing the impacts of sustainable agricultural practices for water quality improvements in the Vouga catchment using the SWAT model. Science of Total Environment 536: $48-58$. 
903 Räike, A., Pietiläinen, O-P., Rekolainen, S., Kauppila, P., Pitkänen, H., Niemi, J., Raateland, A. \& Vuorenmaa,

904 J. (2003). Trends of phosphorus, nitrogen and chlorophyll-a concentrations in Finnish rivers and lakes in $1975-$

905 2000. The Science of the Total Environment 310(1-3): 47-59.

906

907 Salomon, E. \& Sundberg, M. (2012). Implementation and status of priority measures to reduce nitrogen and

908 phosphorus leakage - Summary of country reports.

909 http://www.balticcompass.org/PDF/Reports/SummaryOfCountryReports.pdf. Accessed 1 June 2016.

910

911 Santos, R.M.B., Sanches Fernandes, L.F., Pereira, M.G., Cortes, R.M.V., Pacheco, F.A.L. 2015. A framework

912 model for investigating the export of phosphorus to surface waters in forested watersheds: Implications to

913 management. Science of the Total Environment 536:295-305.

914

915 Saukkonen, S \& Kortelainen, P. (1995). Metsätaloustoimenpiteiden vaikutus ravinteiden ja orgaanisen aineen

916 huuhtoutumiseen. In: Saukkonen, S. \& Kenttämies, K. (Eds.) Metsätalouden vesistövaikutuksen ja niiden

917 torjunta (pp. 15-32). METVE-projektin loppuraportti. Suomen ympäristökeskus, Helsinki. [In Finnish with

918 English abstract].

919

920 Sharpley, A.N., Chapra, S.C., Wedepohl, R., Sims, J.T., Daniel, T.C., Reddy, K.R. (1994). Managing

921 agricultural phosphorus for protection of surface waters: Issues and options. Journal of Environmental Quality

922 23: 437-451.

923

924 Stålnacke, P. (1996). Nutrient loads to the Baltic Sea. PhD thesis, Linköping Studies in Arts and Science, No. $925146,78 \mathrm{pp}$.

926

927 Tamm, C.O., Holmen, H., Popovic, B. \& Wiklander, G. (1974). Leaching of plant nutrients from soils as a consequence of forestry operations. Ambio III(6): 211-221.

929

930 Uusi-Kämppä, J., Braskerud, B., Jansson, H., Syversen, N. \& Uusitalo, R. (1998). Buffer Zones and Constructed 931 Wetlands as Filters for Agricultural Phosphorus. Journal of Environmental Quality 29(1): 151-158.

932

Uusi-Kämppä, J. \& Jauhiainen, L. (2010). Long-term monitoring of buffer zone efficiency under different

934 cultivation techniques in boreal conditions. Agriculture, Ecosystems \& Environment 137: 75-85.

935

936 Uusitalo, R., Turtola, E., Grönroos, J., Kivistö, J., Mäntylahti, V., Turtola, A., Lemola R. \& Salo, T. (2007).

937 Finnish trends in phosphorus balance and soil test phosphorus. Agr. Food Sci. Finland 16: 301-316.

938

939 Vagstad, N., Stålnacke, P., Andersen, H.E., Deelstra, J., Jansons, V., Kyllmar, K., Loigu, E., Rekolainen, S. \&

940 Tumas, R. (2004). Regional variations in diffuse nitrogen losses from agriculture in the Nordic and Baltic

941 regions. Hydrol. Earth Syst. Sc. 8: 651-662. 
943 Valle Junior, R.F., Varandas, S.G.P., Sanches Fernandes, L.F., Pacheco, F.A.L. 2014. Environmental land use

944 conflicts: A threat to soil conservation. Land Use Policy 41:172-185.

945

946 Vuorenmaa, J., Rekolainen, S., Lepistö, A., Kenttämies, K. \& Kauppila, P. (2002). Losses of nitrogen and

947 phosphorus from agricultural and forest areas in Finland during the 1980s and 1990s. Environmental Monitoring

948 and Assessment 76: 213-248.

949

950 Väänänen, R. (2008). Phosphorus retention in forest soils and the functioning of buffer zones used in forestry.

951 University of Helsinki, Department of Forest Ecology. Department of Forest Ecology, Faculty of Agriculture

952 and Forestry. Doctoral Dissertation. doi: 10.14214/df.60.

953

954 Windolf, J., Blicher-Mathiesen, G., Carstensen, J. \& Kronvang, B. (2012). Changes in nitrogen loads to 955 estuaries following implementation of governmental action plans in Denmark: A paired catchment and estuary

956 approach for analyzing regional responses. Environmental Science \& Policy,

957 http://dx.doi.org/10.1016/j.envsci.2012.08.009

958 